\title{
Multi-taxon inventory and landscape characterization in an agrosystem of the Brazilian Midwest targeted for payment for environmental services
}

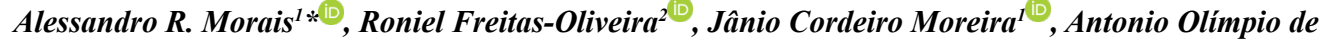 \\ Souza ${ }^{1}$, Bruno Barros Bittar ${ }^{3}$, Fábio Martins Vilar de Carvalho ${ }^{4}$, Gustavo Valtuille de Oliveira ${ }^{1}$, Lia Raquel \\ Souza Santos, ${ }^{5}$ Marco Antônio Guimarães ${ }^{6}$, Nathan Pereira Lima Amorim ${ }^{5}$, Rhayane Alves de Assis ${ }^{7}$, \\ Rinneu Elias Borges ${ }^{8}$, Seixas Rezende Oliveira ${ }^{9}$, Tainã Lucas Andreani ${ }^{10}$ \& Mariana Nascimento Siqueira ${ }^{8}$ \\ ${ }^{1}$ Instituto Federal Goiano, Laboratório de Ecologia, Sistemática e Evolução de Vertebrados, Campus Rio Verde, Rio Verde, GO, Brasil. \\ ${ }^{2}$ Universidade Federal de Goiás, Instituto de Ciências Biológicas, Programa de Pós-Graduação em Ecologia e \\ Evolução, Campus Samambaia, Goiânia, GO, Brasil. \\ ${ }^{3}$ Universidade Federal de Goiás, Instituto de Ciências Biológicas, Programa de Pós-Graduação em Biodiversidade \\ Animal, Campus Samambaia, Goiânia, GO, Brasil. \\ ${ }^{4}$ Instituto Federal Goiano, Laboratório de Biologia Animal, Campus Rio Verde, Rio Verde, GO, Brasil. \\ ${ }^{5}$ Instituto Federal Goiano, Laboratório de Ecotoxicologia e Sistemática Animal, Campus Rio Verde, Rio Verde, GO, Brasil. \\ ${ }^{6}$ Instituto Oswaldo Cruz, Programa de Pós-Graduação em Biodiversidade e Saúde, Manguinhos, RJ, Brasil. \\ ${ }^{7}$ Universidade Estadual Paulista Júlio de Mesquita Filho, Instituto de Biociências, Letras e Ciências Exatas, \\ Programa de Pós-Graduação em Biodiversidade, São José do Rio Preto, SP, Brasil. \\ ${ }^{8}$ Universidade de Rio Verde, Campus Rio Verde, Fazenda Fontes do Saber, Rio Verde, GO, Brasil. \\ ${ }^{9}$ Universidade do Estado do Mato Grosso, Programa de Pós-Graduação em Ecologia e Conservação, Campus Nova \\ Xavantina, Nova Xavantina, MT, Brasil. \\ ${ }^{10}$ Universidade Federal do Mato Grosso do Sul, Programa de Pós-Graduação em Ecologia e Conservação, Cidade \\ Universitária, Campo Grande, MS, Brasil. \\ *Corresponding author: alessandro.morais@ifgoiano.edu.br \\ MORAIS, A.R., FREITAS-OLIVEIRA, R., MOREIRA, J.C., SOUZA, A.O., BITTAR, B.B., CARVALHO, F.M.V., \\ OLIVEIRA, G.V., SANTOS, L.R.S., GUIMARÃES M.A., AMORIM, N.P.L., ASSIS, R.A., BORGES, R.E., \\ OLIVEIRA, S.R., ANDREANI, T.L., SIQUEIRA, M.N. Multi-taxon inventory and landscape characterization \\ in an agrosystem of the Brazilian Midwest targeted for payment for environmental services. Biota Neotropica \\ 22(1): e20211283. https://doi.org/10.1590/1676-0611-BN-2021-1283
}

\begin{abstract}
The replacement of natural landscapes by anthropic environments has led to habitat loss and consequently, to the decline and extinction of many species populations. Several strategies, such as the creation of protected areas (PAs) and payment for ecosystem services have been adopted to mitigate the consequences of this biodiversity crisis. In Rio Verde, Goiás, Brazil, a Water Producer Program (WPP) was established, which provides payment for ecosystem services for the maintenance of riparian vegetation in the region of the Ribeirão Abóbora, a river which supplies the city and metropolitan area. In the absence of environmental diagnostic studies in the region, this present study contributes to reducing some knowledge gaps, through the: (i) characterization of the landscape in the WPP area, (ii) characterization of species of fauna (amphibians, birds, fish, and medium and large terrestrial mammals) and woody flora that occur in this area, and (iii) comparison of species diversity (fauna and flora) found in our study area with the diversity observed in the Cerrado protected area network. Our results reveal a low native vegetation cover ( $21 \%$ of total area), but we recorded 300 total species: 20 species of anuran amphibians, 100 birds, 10 fish, 16 terrestrial mammals (medium and large), and 154 woody plants. Our sample comprises species considered endemic to the Cerrado (e.g., Anuran - Barycholos terntezi and Mammal - Callithrix penicillata), threatened species (e.g., Mammals - Herpailurus yagouaroundi, Myrmecophaga tridactyla and Tapirus terrestris), and exotic invasive species (Mammal - Sus scrofa). The results presented in this study are relevant and may help in the proposal of management actions within the scope of this important program of payment for environmental services. Keywords: Anurans; birds; mammals; fishes; woody plants; exotic invasive species; threatened species.
\end{abstract}


Morais, A R. et al.

\title{
Inventário multi-táxon e caracterização da paisagem em um agrossistema no Centro-Oeste brasileiro alvo de pagamento por serviços ambientais
}

\begin{abstract}
Resumo: A substituição das paisagens naturais por ambientes antropizados tem levado à perda de habitat e, consequentemente, ao declínio populacional e extinção de muitas espécies. Várias estratégias como a criação de Unidades de Conservação (UCs) e o pagamento de serviços ecossistêmicos têm sido adotadas para mitigar as consequências da crise de biodiversidade. Em Rio Verde, estado de Goiás, foi estabelecido um Programa Produtores de Água (PPA) que prevê o pagamento de serviços ecossistêmicos pela manutenção da vegetação ripária na região do ribeirão Abobora que abastece a cidade. Diante da ausência de estudos de diagnóstico ambiental da região, o presente estudo contribui para reduzir algumas lacunas de conhecimento, através da: i) caracterização da paisagem na área deste PPA, ii) caracterização das espécies da fauna (anfíbios, aves, peixes e mamíferos terrestres de médio e grande porte) e flora lenhosa que ocorrem neste local, iii) comparação da diversidade de espécies (fauna e flora) encontrada na área de estudo com aquela observada na rede de áreas protegidas do Cerrado. Nossos resultados revelam baixo índice de cobertura vegetal nativa ( $\sim 21 \%$ da área total), mas por outro lado, registramos 300 espécies, sendo 20 de anfíbios anuros, 100 aves, 10 peixes, 16 mamíferos terrestres (médio e grande porte) e 154 plantas lenhosas. Anossa amostragem compreende espécies que são consideradas endêmicas do Cerrado (p.ex. Anfíbio - Barycholos terntezi e Mamífero - Callithrix penicillata), ameaçadas de extinção (p.ex. Mamíferos - Herpailurus yagouaroundi, Myrmecophaga tridactyla e Tapirus terrestris) ou exótica invasora (Mamífero - Sus scrofa). Os resultados apresentados no presente estudo são relevantes e podem auxiliar na proposição de ações de manejo no âmbito deste importante programa de pagamento por serviços ambientais.
\end{abstract}

Palavras-chave: Anuros; aves; mamiferos; peixes; plantas lenhosas; espécies exóticas invasoras; espécies ameaçadas.

\section{Introduction}

The rapid population decline and the consequent extinction of many species around the world have alarmed scientists and decision-makers (Pimm et al. 2014, Maxwell et al. 2016). To contain the consequences of this crisis, conservation actions must be urgently implemented and under this scenario, the creation and management of protected areas represent the main conservation strategy used worldwide (Rodrigues et al. 2004, Watson et al. 2014). However, due to the scarcity of financial resources and/or little political interest, this strategy has faced some obstacles, such as the lack of adequate funding, physical infrastructure, qualified technical staff, and the land regularization of the areas involved.

Thus, the implementation of alternative strategies is necessary and, in this context, the payment for environmental services (PES) has been adopted as a way to mitigate threats to biodiversity (Wunder 2008). PESs can be defined as an economic instrument that enables recompense and also encourage those people who provide environmental services, improving the profitability of activities of protection and sustainable use of natural resources (Pagiola et al. 2013, Wunder 2005). Currently, PESs are categorized into different modalities (see Pagiola et al. 2013, Wunder 2005), with special emphasis on those actions focused on water supply, which are called Water Producer Programs (WPP) (Pagiola et al. 2013). This PES modality aims to preserve and/or restore riparian vegetation along important water courses with a view to providing water, both in quality and quantity, for public supply (Wunder 2005).

Over the past few years, Water Producer Programs which are certified and regulated by the National Water Agency (NWA), have been implemented in Brazil (Coelho et al. 2021). Most of these initiatives lack detailed environmental diagnoses (e.g., Ruggiero et al. 2019), since little is known about the species of fauna and flora that occur in the areas of these programs. When considering that some fauna and flora species serve as indicators of environmental quality (Burger 2006), by providing a list of species for a given region, one can properly assess the effectiveness of actions implemented in the programs of payment for environmental services, and this can assist in the planning of future management actions. In 2011, the municipality of Rio Verde, located in the southwest of the state of Goiás, in the Brazilian Midwest, implemented a program of water producers in an important local agrosystem. The municipal government is responsible for the coordination of this program and has been promoting good agricultural practices (e.g. containment of erosive processes), as well as promoting management and conservation actions (e.g. fencing and floristic recomposition of water springs located in rural properties of this agrosystem). Despite these efforts, this WPP has had a considerable knowledge gap, due to the lack of detailed environmental diagnoses.

Considering this scenario, we characterized the landscape composition in the area of this WPP for the present study, and also provided a species list of local fauna (amphibians, birds, fish and medium and large terrestrial mammals) and woody flora that occur in this location. Finally, based on an intensive bibliographic search, we compared the species diversity (fauna and flora) found in our study area with the diversity observed in the network of protected areas of the Cerrado.

\section{Material and Methods}

\section{Study area and landscape metrics}

The present study was carried out in the hydrographic microbasin of the Ribeirão Abóbora (abbr. HMRA) (Figure 1), municipality of Rio Verde, southwestern Goiás State, Brazil. The area has 4,992 hectares and it is completely located within the Cerrado domain. The climate of the region is sub-humid tropical, with two well-defined seasons: a dry season (April to September) and a rainy season (October to March). In this area, the remnant vegetation is mainly fragments of forest formations (e.g., gallery forest and dry forest) and savannas (e.g., veredas), which represent areas of permanent preservation (APPs) and legal reserves of the properties located inside the microbasin. The remaining area is represented by anthropic environments, such as agroindustries, livestock and monocultural crops (e.g. soy, sorghum and corn). 

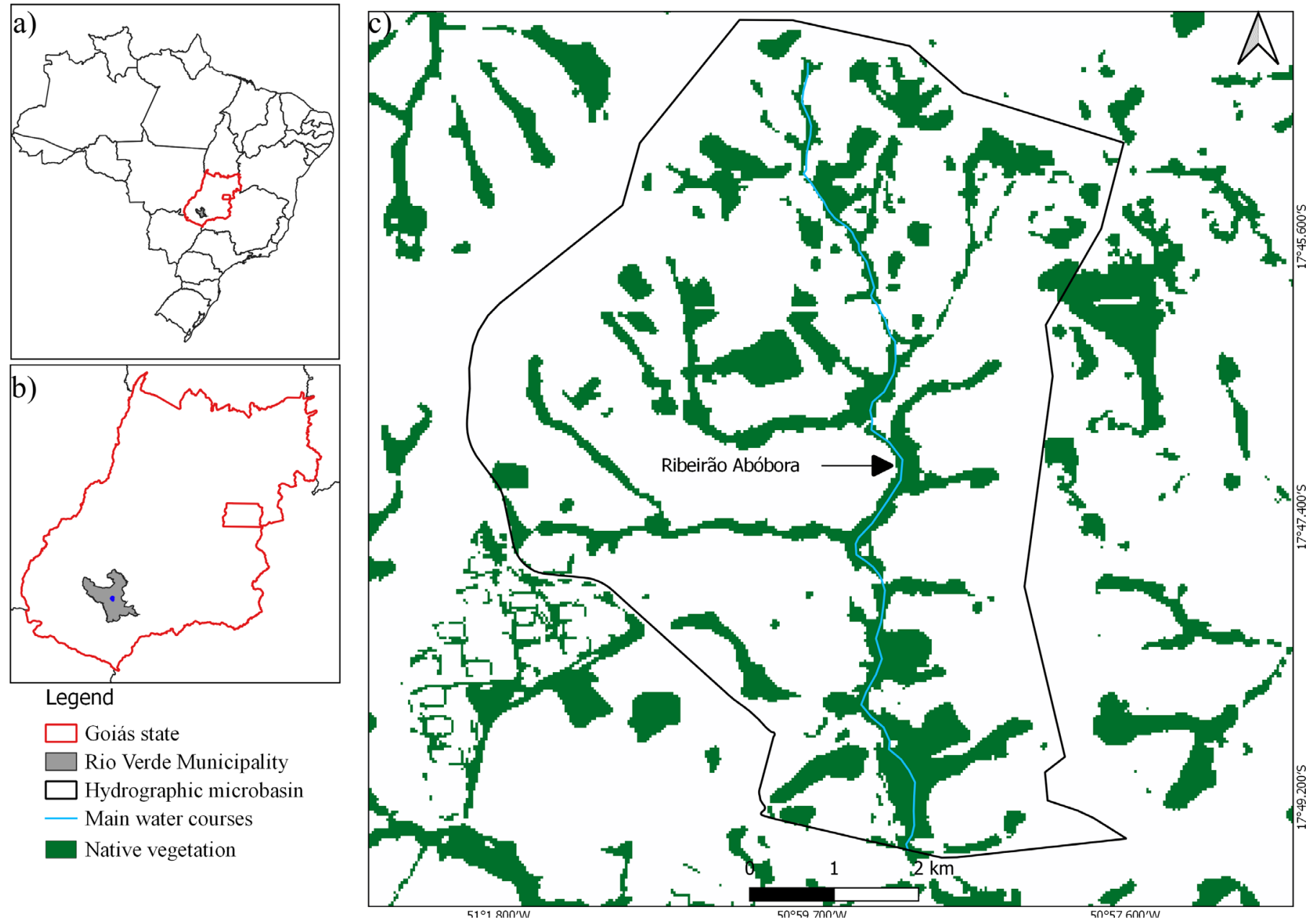

Legend

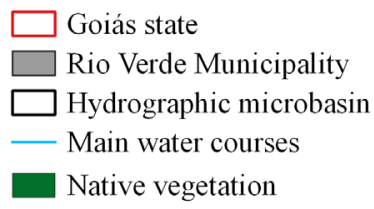

Figure 1. Study area located in the hydrographic microbasin of the Ribeirão Abóbora, municipality of Rio Verde, southwestern Goiás State, Brazil.

The HMRA is of socioeconomic importance, as a considerable portion of the city of Rio Verde's water supply comes from this area. Thus, the municipal government implemented an important mechanism of environmental management in this microbasin, known as the Water Producing Program - WPP ("Programa Produtor de Águas" or "PPA" in Portuguese) in partnership with the National Water Agency (NWA). Since the implementation of the WPP in 2011, the springs of the water courses located inside the area of the microbasin were cataloged, fenced, and went through a process of floristic restoration. In the long-term, these actions target the maintenance of the quantity and quality of the water appropriated for the public supply of the city of Rio Verde.

For landscape characterization of the HMRA, we used a classified image of Mapbiomas collection 5.0 with a resolution of $\sim 5 \mathrm{~m}$ per pixel (Projeto Mapbiomas 2020), which we cropped for the study area and transformed into a binary image (native vegetation $=1$; non-native vegetation $=0$ ). We considered the following as native vegetation: forest, savanna, natural non-forest vegetation, wetlands and swampy areas, which could be present in the MHRA. Then, we used R software (R Core Team 2020) to calculate landscape metrics for the entire microbasin, using the functions $l s m \_$__area and $l s m \_c \_e n n \_m n$ of "landscapemetrics" package (Hesselbarth et al. 2019), from which we extracted the following metrics: percentage of native vegetation in the microbasin $(\% \mathrm{NC})$, number of fragments and mean Euclidian distance for the nearest fragment.

\section{Species inventories}

The characterization of the biota in the study area considered the species richness of amphibian (only anurans), birds, fish, medium- and large-sized terrestrial mammals and woody plants. The field sampling occurred in the permanent preservation areas (PPAs) and legal reserves (LRs) of the rural properties located in the HMRA. It should be noted that the choice of the sampling sites (and the amount of sampling sites), as well as the sampling periods throughout the day, were determined according to the ecological specificities of each taxonomic group, as described below.

\subsection{Anurans}

The sampling of species of anuran amphibians was carried out between February and April 2018 (collecting permit number 47358-1/ SISBIO), using complementary methodologies, such as active search in breeding sites, passive acoustic monitoring, and pitfall traps with drift fences. Suitable sites for reproduction of the anurans were actively sampled following the methodology proposed by Scott \& Woodward (1994). In this case, active search occurred in five waterbodies, each site being sampled on two different nights, in the period from 19:00 to 24:00 $\mathrm{h}$. These waterbodies were characterized as lentic sites, such as dams, ponds and/or swamps. During the search, some species had their advertisement calls recorded, using a Sennheiser ME 66 microphone 
coupled to a MARANTZ PMD 660 or TASCAN DR-40 recorder for later identification in the laboratory.

The passive acoustic monitoring technique was also used for the recording of species in the study area. We installed Tigrinus GT001. T1.0V audio-recorders (https://www.tigrinus.com.br/gravador-deudio) in other five water bodies, which remained for four consecutive nights. Each night, the automatic recorders were programmed to perform five minutes of recording every hour, in the period from 18:00 to 6:00 h. Records were obtained in WAV format, with $48 \mathrm{kHz}$ and 24 bits of resolution. Therefore, we obtained 260 minutes of recordings in each sample point, totaling 1,300 minutes ( $\sim 22$ hours). In the laboratory, vocalizations were analyzed using the Raven 1.4 software (K. Lisa Yang Center for Conservation Bioacoustics 2011). The sound files obtained in this study were deposited in the Neotropical Amphibian Sound Archives Collection (CASAN, in Portuguese) of the Instituto Federal Goiano (IF Goiano - Campus Rio Verde).

Pitfall traps with drift fences, as described by Cechin \& Martins (2000), were used to sample litter amphibians. Six sets of traps were installed in three fragments of the forest formation (e.g., gallery forest and dry forest). For this purpose, we selected the most representative fragments in terms of area. Each set of traps consisted of four 60-liter buckets buried in the soil, arranged in a line and interconnected by a screen of plastic netting, $60 \mathrm{~cm}$ high. The buckets were $10 \mathrm{~m}$ apart from each other. The traps remained open for 10 consecutive days and were reviewed every 24 hours, always in the morning. The nomenclature for amphibian species is in accordance with Frost (2021).

\subsection{Birds}

The sampling of avifauna occurred during the months of March and April 2018, totaling a sampling effort of ten days in the field. To characterize the avian species in the region, the following methods were used: 1) interviews with people living in the study area; 2) linear transects along the forest fragments present in the area, according to the methodology proposed by Burnham et al. (1980, 1981, 1985); and 3) techniques of automatic acoustic monitoring.

The linear transects were according to the shape and size of the 10 fragments. The transects were slowly coursed on foot, recording the species of birds visually and/or by their specific vocalizations. The transects were initiated shortly after sunrise, inside the fragment or at the fragment border, extending for up to four hours. For the visual records of bird species, we used a CANON EOS Rebel T6 EF-S 18-55 f/3.5-5.6 III camera and a CANON EF 75-300mm f/4-5.6 III lens. For the survey of nocturnal birds, we used the technique of passive acoustic monitoring, just as described in the sampling of amphibian species. The analyzed recordings occurred between 18:00 and 06:00 h, totaling a sample effort of 1,300 minutes ( 22 hours) of recordings.

Identification of bird species was based on field guides (Sick 1997, Sigrist 2009, Develey \& Endrigo 2004) and followed the most recent edition of the List of Birds of Brazil (Pacheco et al. 2021). Vocalizations heard in situ and recorded by means of automatic monitoring systems were compared with the archives deposited at the Fonoteca Neotropical Jacques Vielliard (FNJV) of the Museum of Zoology at Universidade Estadual de Campinas (UNICAMP).

\subsection{Terrestrial medium- and large-sized mammals}

The survey of terrestrial mammal species (medium- and largesized) was carried out in March and April 2018, through active search, occasional records, and camera traps. The active search was conducted in 10 forest fragments present in the study area, where we searched for evidence or vestiges of the occurrence of species, as described by Becker \& Dalponte (1991). As evidence of occurrence, we considered: (i) visualization of the individual, (ii) footprints, (iii) burrows (in the case of armadillos), (iv) feces, and (v) sounds registered during the active search (in the case of primates). Occasional records made during car travel inside the microbasin were also considered. Finally, we installed the camera traps (Bushnell model 119436) in five forest fragments, considering the ones most representative in terms of area. We installed one camera trap per fragment, at approximately $50 \mathrm{~cm}$ above the ground, which was placed in the vicinity of trails possibly explored by the animals. The traps remained installed for ten consecutive nights in each one of the sampled fragments and were programmed to make 10 -second videos after being activated.

\subsection{Fishes}

The sampling of ichthyofauna was conducted in the streams (first order) and lakes located in the HMRA (tributary of the São Tomaz River located at the Bois River basin) in April 2018. The sampling occurred in the morning and afternoon periods for 10 days (collecting permit number 34479-1/SISBIO). Specimens were sampled through the Rapid Assessment Program (RAP) with some modifications, such as: 1) interviews with fishermen and local residents; 2) visualization of fish with the naked eye at the edge of water courses; and 3) active fishing with hand nets (mesh size $=2 \mathrm{~mm}$ ), sieves and covo traps, intended to increase the sampling effort in the study area. Active fishing occurred in eight water courses under the influence of the study area, which comprise first-order streams and ponds. Easily identifiable specimens were photographed and released in the same location, following the guidelines of the IBAMA normative instruction $\mathrm{n}^{\mathrm{o}}$ 179, of June 25, 2008.

\subsection{Woody plants}

The records of woody plant species occurred between March and April 2018, through floristic surveys carried out during the course of transects and parcels. The transects occurred in areas of permanent preservation and legal reserves of the rural properties located in the HMRA. In these areas, the sampled fragments were classified as forest (gallery forest and semi-deciduous dry forest, sensu Ribeiro \& Walter 2008) or savanna formations (Cerrado Strictu Sensu and Veredas, sensu Ribeiro \& Walter 2008). The transects occurred both in the interior and at the edge of the fragments, allowing for records of species with different ecological requirements. To increase our sampling effort, we selected one fragment of semi-deciduous dry forest with sufficient size and randomly allocated 20 plots of $10 \times 10 \mathrm{~m}$ area (Felfili et al. 2011). In the plots, we identified only those individuals with circumference at breast height $(\mathrm{CBH})$ greater than or equal to $15 \mathrm{~cm}$. The identification of most specimens occurred in the field, based on their vegetative and reproductive characteristics. However, individuals with difficult identification had samples taken. These samples were packed in plastic bags of 50 liters for later identification in the laboratory with the aid of bibliographic material. We used the Angiosperm Phylogeny Group III classification system (APG 2009).

\subsection{Scientometrics search}

We compared the species richness of amphibians, birds, mammals, fish and woody plants found in the HMRA with those observed in 
protected areas of the Cerrado domain. We searched for studies carried out in the Cerrado protected area network and considered only those studies that provided lists of species for each one of the taxonomic groups mentioned above as inclusion criterion (Supplementary Material 1). For this, we accessed the Scopus (https://www.scopus.com), Scielo (https://www.scielo.br/) and Web of Science (https://www.webofscience. com) databases and used a combination of the following keywords: Anuran OR Bird OR Fish OR Mammal OR Plant*, Species List, AND Inventory AND Cerrado* AND Protected Area* OR Conservation Unit OR Park OR Biological Reserve OR Ecological Station OR Extractive Reserve OR Sustainable Development Reserve OR Wildlife Reserve OR Natural Monument OR Forest OR Environmental Protection Area OR Area of Relevant Ecological Interest and Private Reserve of Natural Heritage. We compiled the species richness in the protected areas of the Cerrado domain for all of the studied taxonomic groups. All of the studies in redundancy were removed and papers published after November 2021 were not included. We did not consider gray literature (e.g. abstracts presented in congresses, theses and dissertations) in our database.

\section{Results}

\section{Landscape characterization}

In 2018 , only $21.32 \%(1,064.73$ ha) of the total mapped area was represented by native vegetation cover (forest, Cerrado Strictu Sensu and veredas), while $78.68 \%$ (3,928.26 ha) was covered by anthropic areas (e.g., plantations and agro-industries). We observed that the remaining native vegetation was distributed in 80 fragments, with sizes varying from 0.05 to 224.23 ha (mean $=13.30 \pm 37.5 ; \mathrm{n}=80$ fragments; Figure 2$)$. Of the 80 fragments, $64(80 \%)$ had less than 10 ha, while only three fragments covered more than 100 ha. The average Euclidean distance between the fragments was $108.78 \mathrm{~m}$.

\section{Species diversity and comparison with protected areas of the Cerrado domain}

We recorded 300 species distributed in the five studied taxonomic groups (Table 1, Figure 3 and 4, Supplementary Material 2). Our sampling includes 20 amphibian species (only anurans), 100 birds, 10 fishes, 16 medium- and large-sized mammals and 154 woody plants. Only 4\% (12 spp.) of the 300 species found in the HMRA are endemic to the Cerrado domain, including five amphibian species (Barycholos terntezi, Dendropsophus cruzi, D. jimi, Pseudopaludicola saltica and Scinax constrictus); one medium- and large-sized mammal (Callithrix penicillata) and six plants species (Aspidosperma tomentosum, Byrsonima basiloba, Dalbergia miscolobium, Miconia burchellii, Ocotea spixiana and Ouratea spectabilis).

Only three medium- and large-sized mammals (Herpailurus yagouaroundi, Myrmecophaga tridactyla and Tapirus terrestris) and one woody plant (Cedrela odorata) are classified as vulnerable according to the National Red List of Threatened Species (Flora do Brasil 2020, MMA 2014). On the other hand, Sus scrofa (a medium- and large-sized mammal) is considered an alien species (Brasil 2017). Species richness in protected areas is greater than that

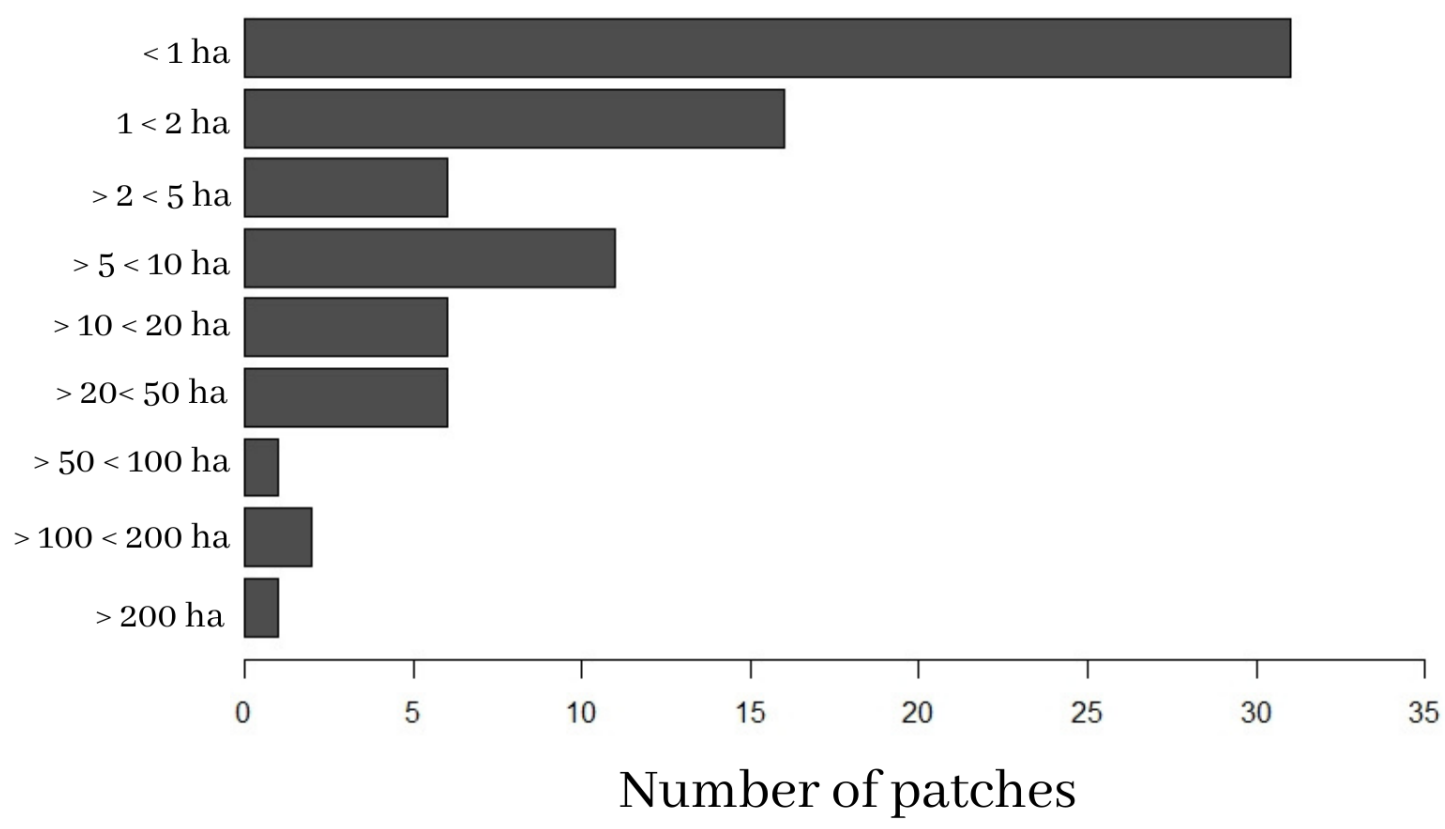

Figure 2. Size in hectares (ha) of native vegetation fragments (patches) in the hydrographic microbasin area of the Ribeirão Abobora, Rio Verde, Goiás. 
Morais, A R. et al.

Table 1. Number of species belonging to each taxonomic group sampled in the hydrographic microbasin area of the Ribeirão Abobora.

\begin{tabular}{cccc}
\hline Taxonomic Group & Total number of species & $\begin{array}{c}\text { Number of endemic species of } \\
\text { the Cerrado domain }\end{array}$ & $\begin{array}{c}\text { Number of threatened species } \\
\text { Amphibian }\end{array}$ \\
Bird & 20 & 5 & 0 \\
Fish & 100 & 0 & 0 \\
Mammals (Medium- and large sized) & 10 & 1 & 0 \\
Plant & 16 & 6 & 1 \\
Total & 154 & 12 & 4 \\
\hline
\end{tabular}
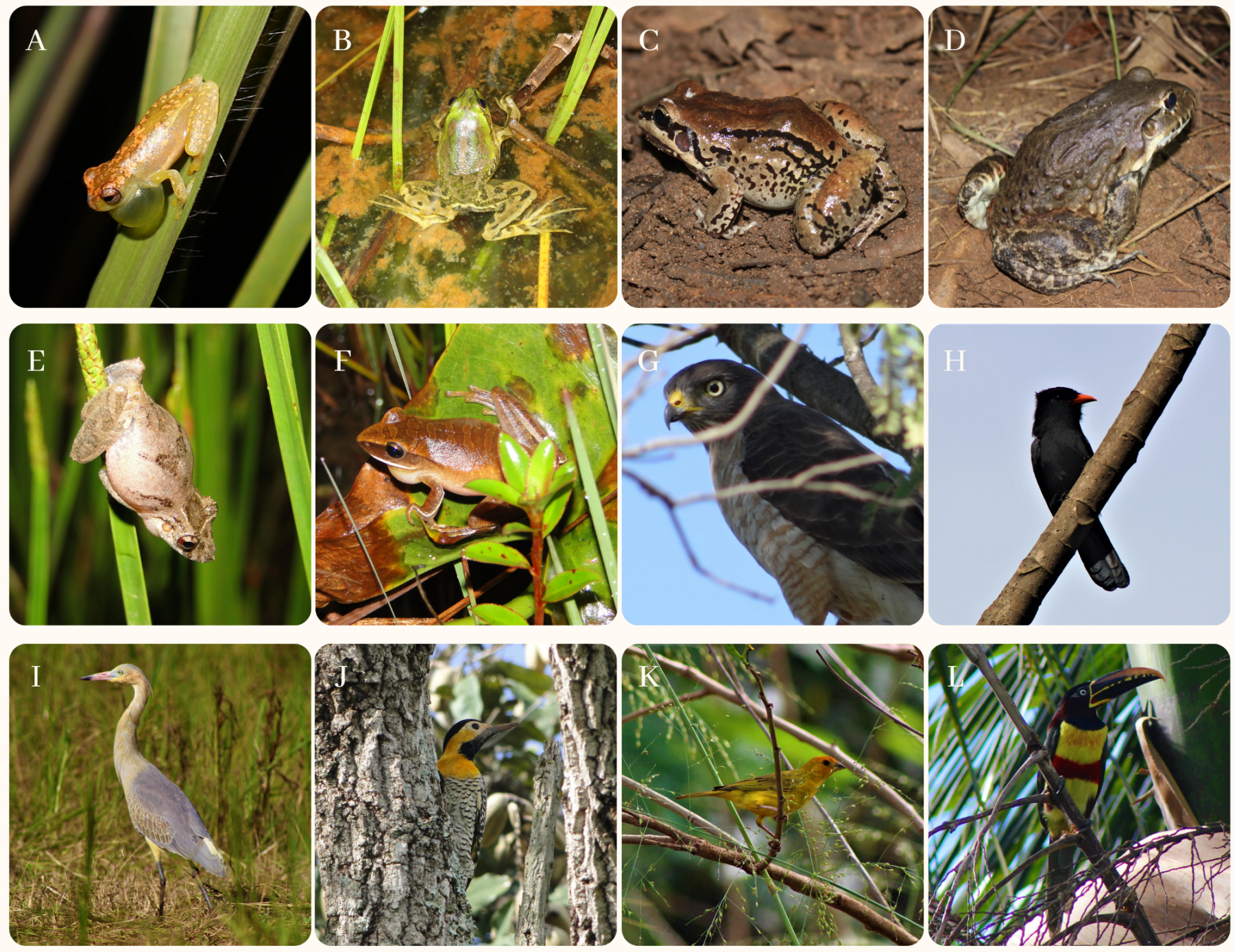

Figure 3. Anuran and bird species registered in the hydrographic microbasin of the Ribeirão Abóbora, municipality of Rio Verde, southwestern Goiás State, Brazil. A) Dendropsophus cruzi, B) Pseudis bolbodactyla, C) Leptodactylus mystacinus, D) Leptodactylus labyrinthicus, E) Scinax constrictus, F) Boana albopunctata, G) Rupornis magnirostris, H) Monasa nigrifrons, I) Syrigma sibilatrix, J) Colaptes campestris, K) Sicalis flaveola, L) Pteroglossus castanotis.

found in the HMRA (Table 2). In addition, we also observed that the species richness of amphibians, birds, fish, medium- and large-sized mammals, and woody plants represent, respectively, $64.77 \%, 45.23 \%$, $39.78 \%, 65.98 \%$ and $68.94 \%$ of the average number of species found in protected areas of the Cerrado domain (Table 2).

\section{Discussion}

In this study, we characterized the landscape attributes and also the species richness of vertebrates and woody plants present in the HMRA, in Rio Verde, GO. We observed a low index of native vegetation cover $(\sim 21 \%)$ in this area, but we recorded an expressive number of species of fauna and woody flora, including some species that are considered endemic to the Cerrado, threatened with extinction or by exotic invasive species. This is a relevant result, since local biodiversity can 

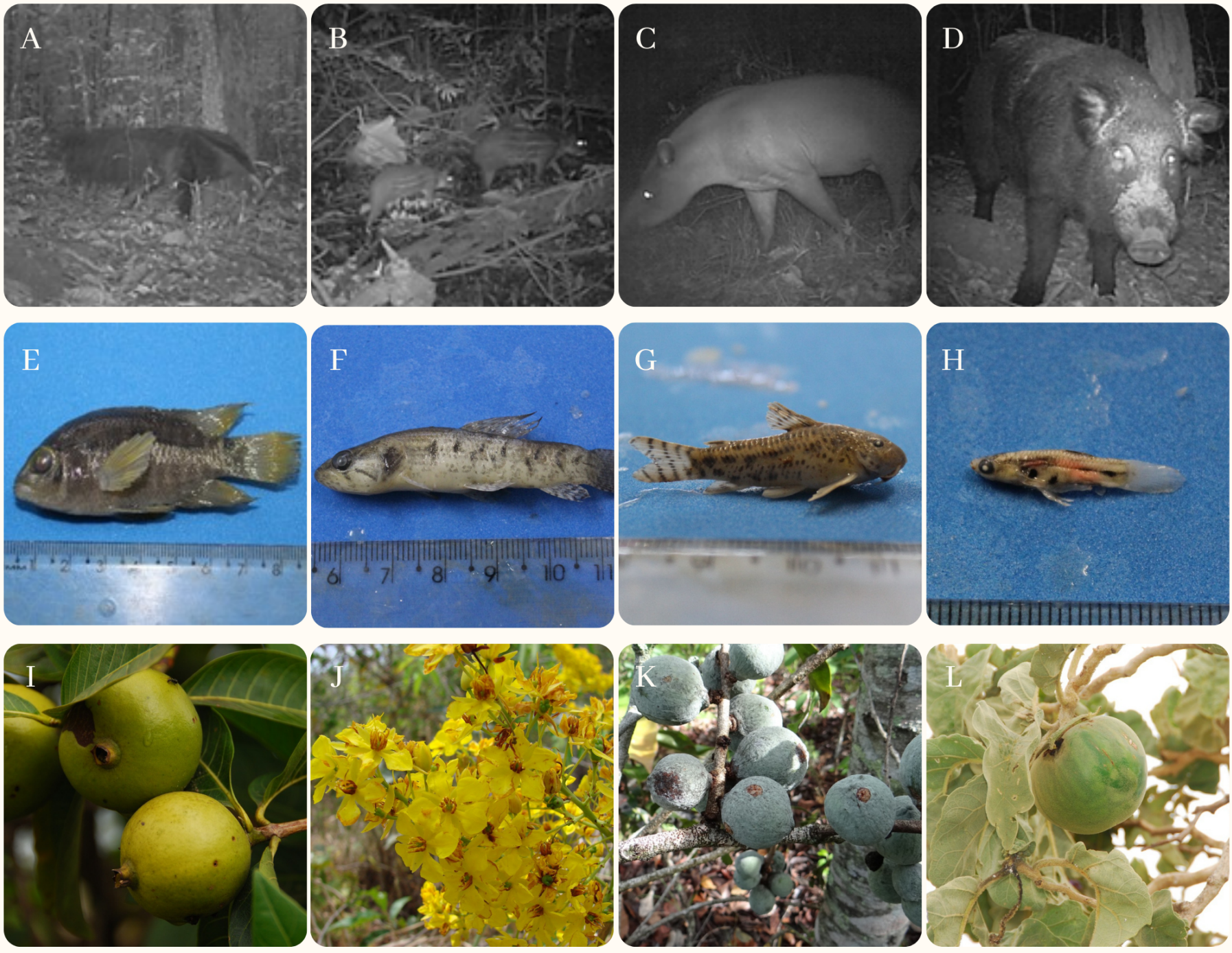

Figure 4. Mammal, fish and woody plant species registered in the hydrographic microbasin of the Ribeirão Abóbora, municipality of Rio Verde, southwestern Goiás State, Brazil. A) Myrmecophaga tridactyla, B) Cuniculus paca, C) Tapirus terrestris, D) Sus scrofa, E) Cichlasoma paranaense, F) Hoplias Malabaricus, G) Aspidoras fuscoguttatus, H) Poecilia reticulata, I) Alibertia edulis, J) Ouratea hexasperma, K) Salacia crassifolia, L) Solanum lycocarpum.

play a key role in the maintenance of important ecosystem services in a given location (e.g., Hooper et al. 2005, Lefcheck et al. 2015). Located in a region of intense agricultural activity, the HMRA consists of rural properties that are beneficiaries of an important program of payment for environmental services, known as the WPP. Since its implementation, this program has promoted actions (the implementation of soil management techniques, fencing of water springs, floristic recomposition of degraded springs and others) that target the maintenance of the springs (PPAs) of water courses located in this agrosystem and that contribute to the public supply of water to the city of Rio Verde. Despite the socioeconomic importance of the HMRA and also the actions already implemented under the WPP, there has been a knowledge gap about the species of fauna and flora that occur in this area. Thus, the present characterization, in addition to filling this gap, has the potential to contribute to future management actions.

The municipality of Rio Verde, a national pillar of grain production, has experienced an intense process of anthropization in recent decades, resulting in the conversion of many natural habitats to agricultural environments
(Siqueira \& Faria 2019). This transformation has been due to the expansion of agricultural activities, which currently occupy about $77 \%$ of this municipality's territory (Siqueira \& Faria 2019). This pattern is repeated at the local scale, as our results showed a predominance of anthropic environments in the HMRA. Only $21.32 \%$ of our study area is represented by native vegetation remnants, which corresponds to the permanent preservation areas (PPAs) and legal reserves (LRs) of the rural properties located in the HMRA. In Brazil, the Native Vegetation Protection Law (No. 12651/2012) provides that deforested PPAs occupied with agroforestry activities through July 2008 are considered to be consolidated and, therefore, the owners of such areas are not required to carry out their full restoration. Considering this scenario, it is noteworthy that part of the PPAs inserted in the HMRA and participants of the WPP would be in this consolidated situation, which would release them from the obligation of their full recovery. Despite this possibility, many of these PPAs have been targeted by WPP interventions since 2011, which has ultimately contributed to their restoration.

Arroyo-Rodríguez et al. (2020) state that, in terms of biodiversity conservation and maintenance of ecosystem services, an optimal 
landscape should contain about $40 \%$ of vegetation cover. These authors also argue that in these landscapes, $10 \%$ of native vegetation should be concentrated in one or a few unique large fragments, and the remaining $30 \%$ should be distributed in a number of small fragments throughout the landscape. In the HMRA, we observed that the remnants of native vegetation are distributed in dozens of fragments (or patches) of varying sizes and within approximately 100 meters of each other. This is important information, based on the theoretical framework proposed by Arroyo-Rodríguez et al. (2020), since understanding the distribution pattern of native vegetation within the HMRA may contribute to the process of decision-making. This enables the proposition of more refined management actions focused on specific areas within the microbasin and this may intensify the returns obtained through the WPP.

Knowing the species that occur in a given area is essential (Bruner et al. 2001), as this allows for more elaborated ecological studies and also for the proposal of more specific management actions. When considering different taxonomic groups, we recorded a considerable number of species of fauna and flora occurring in the HMRA, some of which are endemic to the Cerrado, threatened by extinction, exotic invasive species, or relevant ecological and economic potential. For instance, management actions based on the national action plans (PANs) can be implemented so that the population of these threatened species can be viable in the long term. This implies that educating the local population can help avoid overexploitation of these species and maintain natural habitats suitable for their persistence. On the other hand, management actions must be taken to reduce or remove populations of exotic invasive species (boars - Sus scrofa) observed in the HMRA.

In the Cerrado, protected areas have been shown to be effective in maintaining a high diversity of species when compared to sites which are not legally protected (e.g., Oliveira et al. 2019). This pattern was observed in the present study, since the species diversity of fauna and flora found in the HMRA is lower than the average number of species found in the protected areas of the Cerrado. One explanation for this pattern is that, when compared to the HMRA, the Cerrado protected areas have a greater amount of native vegetation, especially those of integral protection (Françoso et al. 2015), which enables the longterm persistence of native species. Unlike the protected areas, the region in which the HMRA is inserted has experienced a long history of habitat changes, which can decrease the viability of native species populations. Nevertheless, the occurrence of species with specific ecological requirements (e.g. tapir - Tapirus terrestris) in the HMRA can be indicative that interventions carried out under the WPP have positively impacted the local biodiversity.

To our knowledge, this is the first multi-taxon inventory carried out on an agrosystem that is a beneficiary of an important payment program for ecosystem services of water supply. These results represent the first step for conservation and management actions to be properly implemented in this area. In this sense, focusing on future planning, as well as assessing the impacts of WPP, we suggest the establishment of a long-term monitoring program that considers the landscape dynamics and also the species of fauna and flora present in the HMRA.

\section{Supplementary Material}

The following online material is available for this article:
Supplementary Material 1 - List of studies found through the scientometrics search.

Supplementary Material 2 - Species list (Amphibians, Birds, Mammals, Fishes, Woody Plants) registered in the hydrographic microbasin of Ribeirão Abóbora, municipality of Rio Verde, southwestern of Goiás State, Brazil.

\section{Acknowledgments}

The authors are grateful to the Rio Verde municipal environment secretariat for assistance in the field activity. BBB, MAG, RAA, RFO, SRO and TLA acknowledge CAPES (Coordenação de Aperfeiçoamento de Pessoal de Nível Superior); CNPq (Conselho Nacional de Desenvolvimento Cientifíco e Tecnológico); and FAPEG (Fundação de Amparo à Pesquisa do Estado de Goiás) for providing graduate fellowships. ARM is CNPq research productivity fellows (process $\mathrm{n}$. 310658/2020-9). We are grateful for John Karpinski editing.

\section{Associate Editor}

Carlos Joly

\section{Author Contributions}

Alessandro R. Morais: Substantial contribution in the concept and design of the study, contribution to data collection, contribution to data analysis and interpretation, contribution to manuscript preparation and contribution to critical revision, adding intellectual content.

Roniel Freitas-Oliveira: Contribution to data collection, contribution to data analysis and interpretation, contribution to manuscript preparation and contribution to critical revision, adding intellectual content.

Jânio Cordeiro Moreira: Contribution to data collection, contribution to data analysis and interpretation, contribution to manuscript preparation and contribution to critical revision, adding intellectual content.

Antonio Olímpio de Souza: Contribution to data collection, contribution to data analysis and interpretation, contribution to manuscript preparation and contribution to critical revision, adding intellectual content.

Bruno Barros Bittar: Contribution to data collection, contribution to data analysis and interpretation, contribution to manuscript preparation and contribution to critical revision, adding intellectual content.

Fábio Martins Vilar de Carvalho: Contribution to data collection, contribution to data analysis and interpretation, contribution to manuscript preparation and contribution to critical revision, adding intellectual content.

Gustavo Valtuille de Oliveira: Contribution to data collection, contribution to data analysis and interpretation, contribution to manuscript preparation and contribution to critical revision, adding intellectual content.

Lia Raquel Souza Santos: Contribution to data collection, contribution to data analysis and interpretation, contribution to manuscript preparation and contribution to critical revision, adding intellectual content.

Marco Antônio Guimarães: Contribution to data collection, contribution to data analysis and interpretation, contribution to manuscript preparation and contribution to critical revision, adding intellectual content.

Nathan Pereira Lima Amorim: Contribution to data collection, contribution to data analysis and interpretation, contribution to 
manuscript preparation and contribution to critical revision, adding intellectual content.

Rhayane Alves de Assis: Contribution to data collection, contribution to data analysis and interpretation, contribution to manuscript preparation and contribution to critical revision, adding intellectual content.

Rinneu Elias Borges: Contribution to data collection, contribution to data analysis and interpretation, contribution to manuscript preparation and contribution to critical revision, adding intellectual content.

Seixas Rezende Oliveira: Contribution to data collection, contribution to data analysis and interpretation, contribution to manuscript preparation and contribution to critical revision, adding intellectual content.

Tainã Lucas Andreani: Contribution to data collection, contribution to data analysis and interpretation, contribution to manuscript preparation and contribution to critical revision, adding intellectual content.

Mariana Nascimento Siqueira: Substantial contribution in the concept and design of the study, contribution to data collection, contribution to data analysis and interpretation, contribution to manuscript preparation and contribution to critical revision, adding intellectual content

\section{Conflicts of Interest}

The authors declare that they have no conflict of interest related to the publication of this manuscript.

\section{References}

ANGIOSPERM PHYLOGENY GROUP III. 2009. An update of the Angiosperm Phylogeny Group Classification for the Orders and Families of Flowering Plants: APG III. Botanical Journal of the Linnean Society, 161: 105-121.

ARROYO-RODRÍGUEZ, V., FAHRIG, L., TABARELLI, M., WATLING, J.I., TISCHENDORF, M.B. et al. 2020. Designing optimal human-modified landscapes for forest biodiversity conservation. Ecology Letters, 23:1-17. DOI: $10.1111 /$ ele. 13535

BECKER, M. \& DALPONTE, J.C. 1991. Rastros de mamíferos silvestres brasileiros. Brasília: Editora UNB, 180pp.

BRASIL. 2017. Plano Nacional de Prevenção, Controle e Monitoramento do Javali (Sus Scrofa) no Brasil. Brasília.

BRUNER, A.G., GULLISON, R.E., RICE, R.E. \& FONSECA, G.A.B. 2001. Effectiveness of parks in protecting tropical biodiversity. Science, 291: 125-128. DOI: 10.1126/ science.291.5501.125

BURGER, J. 2006. Bioindicators: A Review of Their Use in the Environmental Literature 1970-2005. Environ. Bioindic, 1:136-144. DOI: $10.1080 / 15555270600701540$

BURNHAM, K.P., ANDERSON, D.R. \& LAAKE, J.L. 1980. Estimation of density from line transect sampling of biological populations. Wildl. Monogr. 72: 3-202.

BURNHAM, K.P., ANDERSON, D.R. \& LAAKE, J.L. 1981. Line transect estimation of bird population density using a Fourier series. Studies in Arian Biology, 5: 466-482

BURNHAM, K.P., ANDERSON, D.R. \& LAAKE, J.L. 1985. Efficiency and bias in strip and line transect sampling. J. Wildl. Manage. 49: 1012-1018. DOI: $10.2307 / 3801387$

CECHIN, S.Z. \& MARTINS, M. 2000: Eficiência de armadilhas de queda (pitfall traps) em amostragens de anfíbios e répteis no Brasil. Rev. Bras. Zool. 17(3): 729-740.

COELHO, N.R., GOMES, A.S., CASSANO, C.R. \& PRADO, R.B. 2021. Panorama das iniciativas de pagamentos por serviços ambientais hídricos no Brasil. Eng. Sanit. e Ambient. 26(3): 409-415 DOI: 10.1590/S1413415220190055
DEVELEY, P.F. \& ENDRIGO, E. 2004. Aves da Grande São Paulo: Guia de Campo. Aves e Fotos. Editora, São Paulo.

FELFILI, J.M., EISENLOHR, P.V. \& MELO, M.M.R.F. 2011. Procedimentos e métodos de amostragem de vegetação. Fitossociologia no Brasil: métodos e estudos de casos. Viçosa, MG: Universidade Federal de Viçosa, 86-121.

FLORA DO BRASIL. 2020. Jardim Botânico do Rio de Janeiro. Available at: $<$ http://floradobrasil.jbrj.gov.br/ > . Accessed on 16 december 2021

FRANÇOSO, R.D., BRANDÃO, R.A., NOGUEIRA, C.C., SALMONA, Y., MACHADO, R.B., \& COLLI, G.R. 2015. Habitat loss and the effectiveness of protected areas in the Cerrado biodiversity hotspot. Nat. Conserv. 13: 35-40. DOI: 10.1016/j.ncon.2015.04.001

FROST, D.R. 2021. Amphibian Species of the World: an online reference. Available at: http://research.amnh.org/herpetology/amphibia/ index.php. Accessed on 15 july 2021

HESSELBARTH, M.H.K., SCIAINI, M., WITH, K.A., WIEGAND, K. \& NOWOSAD, J. 2019. landscapemetrics: an open-source R tool to calculate landscape metrics. Ecography, 42:1648-1657.

HOOPER, D.U., CHAPIN III, F.S., EWEL, J.J., HECTOR, A., INCHAUSTI, P., LAVOREL, S., LAWTON, J.H., LODGE, D.M., LOREAU, M., NAEEM, S., SCHMID, B., SETÄLÄ, H., SYMSTAD, A.J., VANDERMEER, J. \& WARDLE, D.A. (2005). Effects of biodiversity on ecosystem functioning: a consensus of current knowledge. Ecol. Monogr. 47(1): 3-35. DOI: 10.1890/04-0922

K. LISA YANG CENTER FOR CONSERVATION BIOACOUSTICS. 2011. Raven Pro: Interactive Sound Analysis Software, version 1.4 [Computer software]. Ithaca (NY): The Cornell Lab of Ornithology; [cited 2021 Aug 24]. Available from: http:// ravensoundsoftware.com/

LEFCHECK, J.S., BRYNES, J.E.K., ISBELL, F., GAMFELDT, L., GRIFFIN, J.N., EISENHAUER, N., HENSEL, M.J.S., CARDINALE, B. \& DUFFY J.E. 2015. Biodiversity enhances ecosystem multifunctionality across trophic levels and habitats. Nat. Commun. 6:6936. DOI: 10.1038/ncomms7936

MAXWELL, S.L., FULLER, R.A., BROOKS, T.M. \& WATSON, J.E. 2016. Biodiversity: The ravages of guns, nets and bulldozers. Nature. 536: 143145. DOI: $10.1038 / 536143^{\mathrm{a}}$

MMA. (2014): Lista Nacional Oficial de Espécies da Fauna Ameaçadas de Extinção. Portaria $\mathrm{N}^{\circ}$ 444. de 17 de dezembro de 2014. Available at: <http:// pesquisa.in.gov.br/imprensa/jsp/visualiza/index.jsp?jornal=1\&pagina $=121$ \&data $=18 / 12 / 2014>$. Accessed on 20 March 2020.

OLIVEIRA, S.R., LIMA-RIBEIRO, M.S., SANTOS, C.E., SOUZA, A.O., VERGILIO, K., ZORTEA, M., GUILHERME, F.A., CARNEIRO, S., VAZ-SILVA, W. \& MORAIS, A.R. (2019). Are protected areas effective to preserve the anurans and promote biodiversity discoveries in the Brazilian Cerrado? J. Nat. Conserv. 52: 125734. DOI: 10.1016/j. jnc.2019.125734

PACHECO, J.F., SILVEIRA, L.F., ALEIXO, A., AGNE, C.A., BENCKE, G.A., BRAVO, G.A., BRITO, G.R.R., COHN-HAFT, M., MAURÍCIO, G.N., NAKA, L.N., OLMOS, F., POSSO, S.R., LEES, A.C., FIGUEIREDO, L.F.A., CARRANO, E., GUEDES, R.C., CESARI, E., FRANZ, I., SCHUNCK, F. \& PIACENTINI, V.Q. 2021. Annotated checklist of the birds of Brazil by the Brazilian Ornithological Records Committee. Ornithology Research, 29: 94-105.

PAGIOLA, S., GLEHN, H.V., TAFFARELLO, D. 2013. Experiências do Brasil em pagamentos por serviços ambientais. São Paulo (Estado). Secretaria do Meio Ambiente/Coordenadoria de Biodiversidade e Recursos Naturais. Experiências de pagamentos.

PIMM, S.L., JENKINS, C.N., ABELL, R., BROOKS, T.M., GITTLEMAN, J.L., JOPPA, L.N., RAVEN, P.H., ROBERTS, C.M. \& SEXTON, J.O. 2014. The biodiversity of species and their rates of extinction, distribution, and protection. Science, 344: 987. DOI: 10.1126/science. 1246752

PROJETO MAPBIOMAS. 2020. Coleção 5.0 da série anual de cobertura e uso do solo no Brasil. Acessed in May 2020.

R CORE TEAM. 2020. R: A language and environment for statistical computing (version 3.4.3). R Foundation for Statistical Computing, Vienna, Austria. https ://www.R-proje ct.org/. Acessed 10 May 2020 
Morais, A R. et al.

RIBEIRO, J.F. \& WALTER, B.M.T. 2008. As Principais Fitofisionomias do Bioma Cerrado. In: SANO, S.M; ALMEIDA, S.P. \& RIBEIRO, J.F. Cerrado: Ecologia e flora. Brasília: EMBRAPA - Cerrados. 151-212.

RODRIGUES, A.S.L., ANDELMAN, S.J., BAKARR, M.I., BOITANI, L., BROOKS, T.M., COWLING, R.M., FISHPOOL, L.D.C., FONSECA, G.A.B., GASTON, K.J., HOFFMANN, M., LONG, J.S., MARQUET, P.A., PILGRIM, J.D., PRESSEY, R.L., SCHIPPER, J., SECHREST, W., STUART, S.N., UNDERHILL, L.G., WALLER, R. W., WATTS, M.E.J. \& YAN, X. 2004. Effectiveness of the global protected area network in representing species diversity. Nature. 428: 640-643. DOI: 10.1038/nature02422

RUGGIERO, P.G.C., METZGER, J.P., TAMBOSI, L.R. \& NICHOLS, E. 2019. Payment for ecosystem service programs in the Brazilian Atlantic Forest: Effective but not enough. Land Use Policy, 82: 283-291. DOI: 10.1016/j. landusepol.2018.11.054

SCOTT, N.J.JR., WOODWARD, B.D. 1994. Surveys at breeding sites. In: Measuring and monitoring biological diversity: standard methods for amphibians, $\mathrm{p}$. 118-125. Heyer, W.R., Donnelly. M.A., McDiarmid, R.W., Hayek, L.C., Foster, M.S., Eds., Washington, USA, Smithsonian Institution Press.
SICK, H. 1997. Ornitologia Brasileira. Rio de Janeiro: Editora Nova Fronteira. SIGRIST, T. 2009. Guia de campo Avis Brasilis: Avifauna Brasileira. Vol. 1. São Paulo: Avis Brasilis

SIQUEIRA, M.N. \& FARIA, K.M.S. 2019. Analysis of the landscape dynamics in the municipality of Rio Verde, Goiás, Brazil: a tool to choose priority areas for conservation. Soc. Nat. 31: 1-20. DOI: 10.14393/SN-v31-2019-38832

WATSON, J.E.M., DUDLEY, N., SEGAN, D.B. \& HOCKINGS, M. 2014. The performance and potential of protected areas. Nature. 515: 67-73. DOI: 10.1038 /nature 13947

WUNDER, S. 2005. "Payments for environmental services: Some nuts and bolts." CIFOR Occasional Paper No.42. Bogor: CIFOR.

WUNDER, S., BÖRNER, J. \& PEREIRA, L. 2008. Pagamentos por serviços ambientais: perspectivas para a Amazônia Legal. Brasília, Ministério do Meio Ambiente, 136p.

Received: 14/09/2021

Accepted: 01/02/2022

Published online: 23/02/2022 